\title{
Powder for Solution Dosage Form
}

National Cancer Institute

\section{Source}

National Cancer Institute. Powder for Solution Dosage Form. NCI Thesaurus. Code C42973.

A powder that yields a solution following reconstitution with an appropriate liquid. 